\title{
Queer Ecologies - Research Paper [May 2021]: The Portrayal of Queerness in Malayalam Films
}

\author{
Ashika Ann Mammen \\ Student \\ MA ECS (English with Cultural Studies) \\ College: Christ (Deemed to Be) University \\ Bangalore, Karnataka, India \\ ashika.mammen@arts.christuniversity.in
}

Abstract

The term "Queer" mainly refers to anything which pertains to sexual behavior, identity or personality which does not conform to the conventional social or heterosexual norms, and assumptions. Being queer was and still is seen as an abnormality by multitudes in the society. Although it has been more than two years since the decriminalization of homosexuality in India, there are still plenty of societies which ill-treat, ostracize and look down upon the LGBTQ communities. The state of Kerala, having the highest literacy rate amongst all the other states in India, also happens to be one of the states which still look at queerness as an illness and an abnormality, which has to be dealt with and 'cured' through counseling and medication. However, in the midst of all these preconceived notions and social injustices against the LGBTQ communities, 'Films' stand as a strong medium of communication and a voice for the LGBTQ communities who are seen as 'nobodies' in our society. Films that have a theme of queerness tend to stand out from the cliché themes such as [heterosexual] love, patriarchy, hegemony, crime, and so on. The focus of this research paper is narrowed down to Malayalam films which stand as a solid foundation in order to show the portrayal of queerness and this is incorporated through a research question. Malayalam films aren't just a 
source of entertainment, but it is also an emotion and an important part of life to the people of Kerala. The portrayal of queerness in Malayalam films have taken a bold stand, with exemplary performances in films like Randu Penkuttikal (1978), Deshadanakkili Karayarilla (1986), Chanthupottu (2005), Njaan Marykutty (2018), Moothon (2019) and more. This research paper throws light upon the various ways in which Malayalam films depict the theme of queerness, which is further carried out by a strong message with regard to the illtreatment of the LGBTQ communities, the harsh realities and injustices faced by these sexual minorities who live a life filled with difficulties and hardships as they struggle to get a well paid job in a our stereotypical society, that labels them off as a bunch of "misfits." Keywords: Queerness, LGBTQ, Gender, Sexual Minorities, Homosexuality, Discrimination, Malayalam, Films, Kerala Introduction

When we hear the term "Queer," what exactly do we associate it with? Do we directly link it to being 'abnormal' or 'extraordinary?' Although the opinions may vary from one person to another, Queerness has been looked upon as something that needs to be treated in such a way that it is brought back to a state of normalcy. What intrigues me more is the question as to how did we all realize and learn what is normal and what isn't? We have collectively been following the practices and lifestyles that were established centuries ago; not giving a thought about whether or not it is the right thing to follow. For instance, the horrific practice of Sati (a ritual wherein a woman sacrifices herself by throwing herself into her husband's funeral pyre) in India made nobody question it for a long period until it was finally abolished. This was an absolutely outrageous ritual that people have blindly followed in the name of religion. The point here is that, this practice, although morally wrong, was looked upon as the "right" thing to do because that is exactly what elements like religion, caste and class teaches us to live by. In my personal opinion, the problem isn't the fact that 
we are confining to "conventional practices" wherein, for example, girls wearing pink and boys wearing blue; but the very fact that we are all quick to judge, label and discriminate individuals who choose a rather different way of life; one that is seemingly "unconventional" to most of us.

The topic of my research is "The Portrayal of Queerness in Malayalam Films," simply because it has taken its place as an eye-catching element, especially because of the unwillingness and incapability of the society to accept and approve of the whole concept of queerness. To add on to it, the existence of the social constructs and preconceived notions about queerness generally tend to make matters worse. According to me, these films are pieces of art that have been delicately crafted in order to depict and carry out the theme of queerness as it stands as a platform which portrays and educates the society about the struggles and intricacies in the lives of these individuals belonging to the LGBTQ communities. I feel that it is absolutely necessary that these mediums are utilized well in order to give these communities a voice and for their development. Considering the fact that queerness has always been a taboo, it created a lot of problems for individuals who knew that they aren't heterosexual, and tried hard to come out in a society where they knew that a complete acceptance from their families, peers, and society is a very rare possibility. However, Kerala, as a state began to improve and develop, when a registered Community Based Organization [CBO] called Queerala was founded by Jijo Kuriakose; this community was for the Malayali LGBTQ people, who were instilled with support as they belong to the gender and sexual minorities. Queerala was originally established in May 2013. Kerala further showed more development as it became one of the first states in India to create a policy of welfare for the transgender community in the year 2016. I feel that when queerness is portrayed through films, it would be an eye-opener for many people who remain completely unaware of the cruelties and harsh discrimination faced by these LGBTQ 
communities. Films are, in my opinion, an excellent medium of communication that is raw and not 'sugarcoated' when it comes to the depiction of a queer theme. This is also linked directly to the skills and abilities of the actors playing their given parts, along with the script and storytelling, adding into picture the location of the shoot, direction- all of this makes it look real and extremely raw, which gives the portrayal of this theme more life to it.

\section{Literature Review}

1. Queer Politics in Cinema: The Evolving Paradigms of Representation of Queer in Malayalam Movies - Christina Mary Georgy

This paper throws light upon the discrimination of the LGBTQ communities in India, where the concept of sexuality is highly problematic as it is completely abnormal to be anything but heterosexual. Although there are many ancient religious texts which depict sexual acts including homosexuality, prostitution and sadomasochism, the Indian culture is still very hypocritical about sexual subjects as they're considered as a taboo. The paper further talks about Malayalam films being heteronormative over the years and that there have been a considerable treatment of the concept of sexuality. This paper has strengthened my research paper which is on 'The Portrayal of Queerness in Malayalam Films' due to its stance on the developing patterns of the queer films which has seemingly changed the outlook of the audience towards the sexual minorities. These films have created awareness about the struggles faced by the LGBTQ communities as well. The sexual minorities sunk down to the lowest of conditions and they were and still are falsified by our society which is a phallocentric or a patriarchal one.

2. What Bollywood Can Learn From Malayalam Cinema's Portrayal of the LGBTQ Community - Parthiv Kidangoor

This article talks about how cinema has been a major force in India as it adds dimensions to the socio-cultural and political environment. It talks about how queer 
characters are developed in films for comic relief, as sidekicks, or as villains. This article supports my research paper in terms of the fact that films have always had a large impact on its audience. Through this powerful source of communication, the concept of queerness has been brought out to the society that looks upon the LGBTQ communities as a downtrodden bunch. The power vested in the impact that films bring to the society is extremely immense as it creates a sense of awareness as to how and what kind of grave situations these sexual minorities face in our society even to this day. They're generally looked upon in a very negative light and are ostracized from the society because they do not fit into the normalcy of the society as they're considered to be abnormal and a burden to their families. Queer characters in films are portrayed in a demoralized manner and this is pretty much the reflection of their position in society.

3. 'Moothon': Finally a Malayalam film that depicts queer love sensitively and without stereotypes - Navamy Sudhish

The article is a review of the latest film on queer love which released in 2019. Moothon isn't just a film about gay love, but it is a multilayered film with a large thematic depth, exploring the spectrum of queerness with a raw and lyrical finesse. This article backs up my research paper as it gives a solid review of the most recent Malayalam film about queer love. The film Moothon, which was released in 2019 was an extremely gut-wrenching reality along with its vibrant shades of pain and pleasure portrayed beautifully through the characters in the film. Although the film was not a commercially loaded one, it hadn't failed in captivating its viewers through the rawness of its characters, and of course, its exemplary storyline which depicts the dark and daunting realities that exist in the world. The film has brought out the concept of queer love in an astounding manner and this film happens to be the very first queer film which I watched in a theatre and it was such a wonderful experience to be a part of something so extraordinary and unique. As a part of the audience, I personally 
felt very disturbed as it was so upsetting to see the plight of the two men who loved each other but couldn't be together due to the fact that they dwelled in a society which looked upon homosexuality as a wrongdoing. This film also happens to be one of the three films which are a major part of my research paper. Moothon is a film which portrays queer love in a very unique manner, intriguing the audience who are taken through a heart-wrenching turn of events which delve deep into a dark world full of lust, betrayal, murder and flesh trade. Therefore, this article serves as an excellent source which supports my research paper. 4. Regional Cinemas That Have Represented The Queer Community - Krupa Joseph This article points out the list of regional films representing the queer community. In India, the first film which was about homosexuality was released in 1978. Many of these films were commercially acclaimed, which means that people were more tolerant and inclusive back then when compared to what people have become today, or that filmmakers saw an opportunity to educate the public more than just providing meaningless entertainment. The article lists out a set of regional films like:

'Deshadanakkili Karayarilla' [1986] -Malayalam 'Naanu Avanalla....Avalu’ [2015] - Kannada 'Arekti Premer Golpo’ [2010] - Bengali

This article provides a base for my research paper which is about Malayalam films that portray queerness. Malayalam being a regional language released a queer film in 1986 called 'Deshadanakkili Karayarilla.' This film is one of the three films that are a part of my research paper. Being a queer film in the Malayalam film industry, 'Deshadanakkili Karayarilla, ' was truly a work of art which portrayed homosexuality in an extremely subtle manner. The film holds an effective stance on the intimate friendship between two school girls who find solace in each other. 


\section{5. 'Radu Penkuttikal' to 'Moothon': How Malayalam Cinema Has Depicted LGBTQI+ Communities - Cris}

This article tells us that even though the Malayalam Film Industry has won multiple awards and laurels for making films of a progressive nature, the depiction of LGBTQI+ communities has either been too wrong or just absent. The article talks about how Malayalam films improved in terms of their narratives and production by giving us a timeline of the films embracing the theme of queerness from 'Randu Penkuttikal' in 1978 to 'Moothon' in 2019; the former being the first homosexual Malayalam film to be released and the latter being the best rated Malayalam film on homosexuality. This article provides content to my research paper as it talks of the progression made in the field of queer films in the Malayalam film industry. The progression further results in a better and more vivid form of portrayal of queerness in Malayalam films. The films and its storylines have gradually developed with the passing generations and have proved to be very creative and noteworthy as the audience have a broader outlook and a much wider perspective about the concept of queerness when compared to what it used to be four decades ago. According to me, this article educates its reader on the evolution of the portrayal of queerness in Malayalam films; a noteworthy and marvelous journey with plenty of hardships and the blood and sweat of many people who have made the films what they are today - an eye opener and a thread of meaningful and beautiful stories.

\section{Brief Methodology}

This research paper entitled 'The Portrayal of Queerness in Malayalam Films,' is a case study on the ways in which Malayalam films depict the theme of queerness. There are three films which depict queerness that have been employed in this research paper. They are as follows:

\section{Deshadanakkili Karayarilla (1986)}


- $\quad$ Chanthupottu(2005)

- $\quad$ Moothon (2019)

In order to understand the theme, I watched and analyzed the above three films in such a way that every tiny as well as large detail, be it the gestures of the character in the film or the ambience of the shoot location were all duly noted and understood in terms of the existing problems which the gender and sexual minorities have been facing for decades. Films are a good source of information and detail as it further exposes us to minute details which generally go unnoticed by many among the audience. These minute details present in the films form the crux of this research paper which has a foundation formed by these details noted in all the three films, which would further help us raise questions as to why something happened the way it happened. There are articles related to queerness in films, which has been referred to in order to get more credible information for the topic of this research paper. The research question of this research paper is as follows: 'How has the Malayalam film industry portrayed 'Queerness' in their films and what have these films conveyed to its audience in terms of discrimination and ill-treatment of gender and sexual minorities?' Theoretical Framework

This research paper is based on a theory from a book called Amorous Acts by Frances L. Restuccia. The fifth chapter of this book is called 'It's a Queer World, After All,' from which I have taken the theory that forms a base for my research. The chapter begins with a quote from another book named Beyond Sexuality by Tim Dean. "Queer politics involves not only the negative effort to resist norms, but also the positive work of intense, almost superhuman loving” (Dean 119). The chapter brings out the Lacanian view on love which holds a very significant stance in queer theory. Jacques Lacan's theory of love opposed the system of reasoning that love is 'feminine' and is unrelated to masculinity. There is also another line which states, "A stress in queer theory on what in Lacanian parlance might be 
called the "beyond," defined as being "outside the limits of the law"," (Restuccia 119). The above few lines stand as the foundation for my research paper. The Lacanian perspective on love being the significant element in queer theory which is called the 'beyond' is clearly defined as something which is 'unlawful' to the society. This theory stands as a voice for the sexual minorities who face many struggles in the society. This theory also opposed the heterosexual normalcy that has been strived to be maintained. The research paper on "The Portrayal of Queerness in Malayalam Films" is linked to this theory as it talks about the concept of queerness being unnatural and unlawful, making it extremely difficult for people to accept their true sexuality in a society like ours. However, I think that, through films, this concept began to spread far and wide in a completely different manner because of the methods used to portray queerness, and it has begun to gain good responses and acceptance in the society as well. The concept of queerness, even to this day, isn't something that is accepted by everyone in the society, but there have been considerable changes when compared to the past few decades when the society remained very uptight about it and completely against it, further leading to discrimination resulting in the horrendous and brutal treatment of gender and sexual minorities, out of which some of them have even been murdered by their kin for choosing this way of life.

Data Analysis and Interpretation

This research paper on "The Portrayal of Queerness in Malayalam Films" is based on three films namely, Deshadanakkili Karayarilla (1986), Chanthupottu (2005), and Moothon (2019), which carry out the portrayal of queerness in a different, yet unique manner.

The first film, Deshadanakkili Karayarilla, was directed by Padmarajan and released in 1986, starring Mohanlal, Karthika, Shari and $\underline{\text { Urvashi. }}$ The film is about two girls, Nirmala and Sally, who go to a boarding school and decide to elope as they're on a picnic from school. They feel unwanted at school and home and decide their own fate by eloping. Sally is 
seen to be a very bold and boisterous character, whereas Nirmala is gentle, shy and quiet. There is a scene in the film where the two girls go shopping to buy new clothes and they use one trial room to change their clothes (00:32:12) and this is shown in a very subtle manner making it look very normal but at the same time, it adds to the intimate bond of the two girls. After they leave the store, it is clearly seen through the choice of dressing of the two girls $(00: 32: 18)$ as to who has a more masculine side to her, and that is Sally, who wears a pair of pants and a shirt tucked in, whereas, Nirmala wears a dress and is seen to be more feminine. There is another scene in the film where Sally decides to cut her hair (00:48:09) in order to go unrecognized when her picture comes in the newspaper saying that the two girls are missing. This shows that she's the kind of girl who makes bold decisions and is a daredevil, whereas Nirmala isn't keen on being and doing such bold things. Another scene in the film shows Sally putting her hands on Nirmala's shoulders (00:53:23), and tells her not to worry as they talk about their families coming in search of them, depicts how Sally manages the situation and always has a plan as to what they should be doing next, and at the same time, it also shows how she is there for Nirmala as her only pillar of strength and is very protective of her as well. In this scene, Sally's posture and body language matches up to that of a masculine figure whereas Nirmala is seen to be shielded and safe in her arms. There are a few parts in the film (00:58:35) (00:58:41) (00:58:51) (00:59:08) (00:59:44) (01:00:53) which show the two girls from a distance and this scene is shot in such a way that it makes Sally look like a man; this detail is something that makes their friendship look more intimate and creates an impression in the minds of the audience about their unusual bond. There is yet another scene in the film where the girls, who are at a restaurant, are confronted by a man called Harishankar, who says that he didn't want to disturb them because he thought they were a couple as he was sitting behind Sally, who looked like a man to him (01:04:16). This shows how they're being looked through the public eye in a very unusual manner. In the film, it 
clearly shows how uncomfortable and possessive Sally gets when Harishankar gets close to Nirmala (01:06:17), which also results in jealousy and this opens up the character's hidden sexuality to us. Nirmala falls in love with Harishankar as she sees in him a masculine figure who'd be there to protect her and this begins to affect Sally (01:12:10) (01:16:53) who sees Nirmala as her 'everything,' but she suppresses her feelings and is happy for her friend. The film also shows how Sally comes back to their room where Nirmala was about to commit suicide because she felt like she had nobody by her side. That is when Sally holds her and tells her that she is always there for her (02:15:09) and this is seen as an eruption of their love in the film. The film ends with both the girls found dead in bed, as they felt that it was their last and final resort and that their one and only way to be together was to be united by death because life kept throwing situations that could separate them from each other (02:17:39).

The second film, Chanthupottu, was directed by Lal Jose, and released in 2005, starring Dileep and Gopika. The film is about a young man named Radhakrishnan, fondly known as Radha, who behaves like a girl as he was brought up like one by his grandmother (00:04:38). The people of his town tease him and harass him for behaving like a girl as he possesses a character that is very effeminate in nature. There is a scene in the film which introduces Radha once he's a grown up, and it shows him playing Bharatanaatyam with his female friends (00:16:39) and this gives the audience an idea as to what he has become due to the fact that his grandmother raised him like a girl. In another scene in the film, Radha is seen to warn his childhood friend Malu about Kumaran, a money lender who is trying to win Malu's heart. Kumaran teases Radha for his effeminate ways and Radha responds by talking back to him in a very ladylike manner (00:26:21). The film shows another scene in which Radha's father comes back from jail and he is shocked to see his son dressed and behaving like a woman and he criticizes him (00:33:06). There is a scene in the film wherein Radha is seen to be harassed and his clothes are stripped off by Kumaran's friends who wanted to 
check whether he is a man or a woman. His mother runs to his aid and consoles him (00:40:34). He is seen as a curse to the village and is laughed at and mocked by everyone because of his dressing and behavior, which is seen as 'unsuitable' for a man. He is even looked down upon by his own father who says that he isn't sure if his son is a man $(00: 41: 11)$ and Radha overhears everything and weeps bitterly, when his mother comes to him (00:42:12) and tells him that he has to prove everyone wrong by showing them that he is a man through his character and dressing and that girls should desire him and try to woo him. This film shows how many problems Radha faces due to his choice of dressing and behavior. It comes to a really brutal point where he is labelled as the 'curse of the village' and is asked to leave the village, for the good of its people (00:56:47). There is a scene in the film (01:04:29) where Radha argues with his father and tells him that he is a man and he isn't leaving the village, and to this his father ridicules him. The fact that he knows that he is a man but doesn't behave like one is well portrayed to the audience as Radha stands up for himself trying to prove to his family who pays no heed to what he says but looks at what he is on the outside. They don't take into consideration the fact that he is in love with Malu, but puts him down for his set of choices and character which is, by convention, well-suited for a woman and not a man. Kumaran tries to kill Radha for trying to take Malu as his wife (01:07:26) and he fights with him and leaves him to drown in the sea. He is saved by Freddie, who runs a restaurant. Freddie lets Radha stay at his home with his sister Rosie, who criticizes him for doing chores and working in the kitchen saying that it is a girl's job to do so and she asks him to dress like a man $(01: 16: 10)(01: 23: 30)$. There is another scene in the film when Radha saves Rosie from Cleetus who is her brother's enemy, and Radha gets beaten by him. Seeing this, Rosie begins to see her late brother Jonfy in Radha. (01:28:54). This is a scene which aims to show that Radha, who is effeminate has begun to show signs of masculinity by standing up to protect Rosie from being molested by Cleetus. The most 
common characteristics of a man begin to appear as Radha changes his effeminate nature and becomes the man that the society wants him to be. There is another scene in the film where Freddie, Rosie and their friends join together and give Radha a makeover so that he'd look masculine (01:31:54). This clearly shows that Radha, whose effeminate ways made everyone come to a conclusion that he would be mistreated, harassed and looked down upon as an abnormal individual. And hence, he was forced to change his ways and taught how to fight and dress like a man to prove to everyone else that he is masculine in nature so that he'd be able to earn a good reputation and respect from people. The whole film is based on the struggles faced by Radha to live in his village filled with stereotypical people who have extremely shallow mindsets. The film brings to its audience the concept of queerness seen as a very shameful thing which shouldn't be practiced or followed. The film gives a clear-cut message that although the protagonist likes his effeminate ways, he had no choice but to change himself for the society that mocked and looked at him as a curse.

The third film is Moothon, directed by Geethu Mohandas and released in 2019, starring Nivin Pauly, Roshan Mathew and Sanjana Dipu. The film is about a young girl called Mulla, who disguises herself as a boy and sets out to find her brother Akbar. In the film, Akbar and Ameer share a unique and extraordinary love. Ameer is a deaf and mute man who falls in love with Akbar who equally finds himself drawn to Ameer. Their love is extremely sensitive and gentle and it is seen as a huge wrongdoing when their families get to know of their relationship. There is a scene in the film when Akbar stands in front of the mirror and smiles at his reflection- his eyes rimmed with kohl, and his face beaming with emotions. In the midst of the scene, there is a look of happiness and contentment in his eyes as he looks at his reflection, and this is right before he goes to Ameer's house, where he lights a cigarette and knocks his door. Ameer opens the door and looks at Akbar who nervously stares at him as he feels there is tension between them. Ameer, however, is at ease and lets 
him in. The love between the two is so mesmerizing as the tension is intensified through their gestures. Their love is portrayed through unsaid words and there is a transition seen in Akbar as he moves from his serene home in the Lakshadweep Islands to the dark and dingy streets of Kamathipura in Mumbai where he becomes a gangster as he goes into a world of crime, lust, flesh trade and murder. Mulla comes to Kamathipura in search of Akbar, who is her 'Moothon' which means 'elder brother.' The quest to find her brother is what forms this film, which further brings in the gay love of Ameer and Akbar. Ameer commits suicide because his kin forbids him from living with Akbar and this signifies the plight of the sexual minorities who struggle to open up to the society about their sexuality fearing harsh judgment and oppression from the society. Akbar, on the other hand, becomes a gangster and moves on with his life, suppressing his memories with Ameer and his life at the Lakshadweep Islands. There is also a huge transition seen in the character of Akbar who was seen as shy and meek in the beginning but later on becomes a merciless and brutal gangster. This metamorphosis in his character is symbolic of the proximity change from the beautiful and serene Lakshadweep Islands to the dark and eerie streets of Kamathipura, where danger and betrayal lurks in every dingy corner. The love between Akbar and Ameer is portrayed in an extremely vivid manner as they both swim in the ocean and share a moment which speaks volumes about how they feel about each other. Ameer even communicates to Akbar using sign languages and tells him about Mumbai and its beauty. However, Akbar ended up in the wrong places in Mumbai unlike the ones that Ameer spoke about. This film brought about a lot of happiness and stood as an embodiment of empathy and respect towards the sexual minorities of Kerala and many other states in India.

Research Question: How has the Malayalam film industry portrayed 'Queerness' in their films and what have these films conveyed to its audience in terms of discrimination and illtreatment of gender and sexual minorities? 
Answer: The Malayalam film industry has put up excellent performances from various films to portray queerness. The three films employed in this paper have neatly conveyed the concept of queerness along with a strong message to its viewers as well. In the film Deshadanakkili Karayarilla, Nirmala and Sally share a unique bond, rather, one that is very intimate. Queerness is portrayed through the character of Sally, who cuts her hair and dresses like a man and suppresses her feelings and emotions that she has for her best friend Nirmala, fearing the judgment of the society. She is seen to be very protective of Nirmala, especially when she sees her bonding with Harishankar whom she sees as a threat to their friendship and their plan of eloping. Sally's character brings out a very bold and possessive stance in their friendship, whereas Nirmala is seen as the meek and gentle character. Sally is also seen as a very shrewd, blunt and rustic person and never easily trusts anyone. She is seen as a character that one would never mess around with. In a subtle way, the film portrays Sally as a man in their relationship, and Nirmala as the woman due to the obvious femininity that her character is made up of. Sally and Nirmala commit suicide in the end as they feel that death is the only safe place where they can be together with each other in peace. They look at it as their last resort and their safe haven. They chose their own fate and let nobody else decide for them.

In the film Chanthupottu, Radha is a man who has an effeminate nature, due to which, the rest of the villagers mock and criticize him. He falls in love with Malu, his childhood friend, who equally holds a special place for Radha in her heart. The fact that Radha doesn't do work that men do and that he dresses and talks like a woman makes the villagers ridicule him and even end up saying that due to Radha's effeminate ways, he is a curse to their village. This makes it difficult for Radha who is looked down upon even by his own parents. On leaving his village, he is attacked by Kumaran, but is saved by Freddie, who helps him to change his ways for the better. A new version of Radha who changed his effeminate ways comes back to his village and fights Kumaran, who is later asked to leave the village. He then 
goes to Malu and his baby who awaits his arrival, and on seeing that his baby boy is wearing bangles and a hair tie, he immediately takes off the accessories and tells Malu that their baby is a boy, and that he should grow up like a boy. This film gives us a true reflection of how the society functions in terms of dealing with the concept of queerness. The society instills into the minds of the youth, a set of ideas and notions which are to be followed as rules or norms. These ideas and notions of the society are the main cause of the rate of suicides among sexual minorities who feel suffocated as they live their lives the way in which the society wants them to live it; taking the lives of Sally and Nirmala as an example. The society lives their lives for them, telling them what they should be, and who they should marry and how they should live. They live with no freedom of expression and choice. In the film Moothon, the lack of freedom of choice and expression is seen clearly through the eyes of Ameer who couldn't even verbally express his feelings, yet he loved Akbar through his unsaid words and gestures. Akbar and Ameer share a love that is so pure and gentle as they cared about none who were against them. Ameer was beaten when his love was revealed to his family who stood in their way with a marriage proposal for Ameer, who decided his own fate and hung himself as he couldn't imagine living a life on someone else's terms. The moment that Akbar spends in front of the mirror is seen as a very significant moment when he looks at himself and smiles and this is seen as a form of acceptance and peace made with who he actually is and how he wants to live his life. All these characters from these films are striking examples of the brave hearts that exist in our society, facing oppression, being ill-treated, and looked down upon as the 'abnormal.' They are human; just like any of us. Just that they're unique and rare humans who strive to live a normal life in a toxic society like ours. We are no different from them; probably, just the fact that they are far more pure at heart than we'd ever be.

Conclusion 
This paper employed three films namely, Deshadanakkili Karayarilla (1986), Chanthupottu (2005), and Moothon (2019), which throws light upon the portrayal of queerness in Malayalam films. Through these films, the ways in which queerness is portrayed through the scenes and the splendid performances of the actors who played the characters in the films putting in their raw emotions and turning it into a work of art, portraying their problems faced due to their queerness, how they face their fate and how society deals with them has been mentioned in a detailed manner. The paper also briefly mentions the struggles faced by the sexual minorities in our society. 


\section{Works Cited}

“'Randu Penkuttikal' to 'Moothon': How Malayalam Cinema Has Depicted LGBTQI Communities.” The News Minute, 14 Jan. 2020, www.thenewsminute.com/article/randu-penkuttikal-moothon-how-malayalamcinema-has-depicted-lgbtqi-communities-115344.

"Amorous Acts." Google Books, Google, books.google.co.in/books?id=4R9X58ioH8C\&pg=PR15\&lpg=PR15\&dq=amorous+acts+as+a+queer+world+afterall\&sour ce=bl\&ots=vJeBgyuLVJ\&sig=ACfU3U3SXcGo_BHwRgJdpgmrIBq0QtJipw\&hl=en \&sa=X\&ved=2ahUKEwj8_cfAkbnpAhVwxzgGHf6vDpAQ6AEwAHoECAoQAQ\#v $=$ onepage $\& \mathrm{q}=$ amorous acts as a queer world afterall $\& \mathrm{f}=\mathrm{false}$.

“Chanthupottu Review: Sulekha Creative.” Community, creative.sulekha.com/chanthupottureview_203781_blog.

Chitrangada, Priyadarshini, et al. "How Malayalam Cinema Portrays The LGBTQ Community." Youth Ki Awaaz, 13 Feb. 2017, www.youthkiawaaz.com/2017/02/alternate-sexuality-in-malayalam-cinema-andindian-diaspora/.

“Desatanakkili Karayarilla (1986) A Review plus Tribute to Padmarajan.” Filmcholy, 5 Apr. 2019, www.filmcholy.com/features/desatanakkili-karayarilla-1986-a-review-plustribute-to-padmarajan/.

"From 'Deshadanakili Karayarilla' to 'Aami': The Gay Identity in Malayalam Films." The News Minute, 11 July 2018, www.thenewsminute.com/article/deshadanakilikarayarilla-aami-gay-identity-malayalam-films-84563.

George, Anjana. "Queerlessness of Mollywood - Times of India." The Times of India, The Times of India, 19 Mar. 2019, 
timesofindia.indiatimes.com/entertainment/malayalam/movies/news/queerlessness-ofmollywood/articleshow/68481290.cms.

Georgy, Christina Mary. "Queer Politics in Cinema: The Evolving Paradigms of Representation of Queer in Malayalam Movies.” SMART MOVES JOURNAL IJELLH, ijellh.com/OJS/index.php/OJS/article/view/8565.

Joseph, Krupa, et al. "Regional Cinemas That Have Represented The Queer Community." Gaysi, 24 Nov. 2016, gaysifamily.com/2016/06/25/regional-cinemas-representedqueer-community/.

"Moothon Actor Roshan Mathew on His Breakout, and Playing a Speech-Impaired Gay Man in Geethu Mohandas' Film- Entertainment News, Firstpost.” Firstpost, 27 Nov. 2019, www.firstpost.com/entertainment/moothon-actor-roshan-mathew-on-his-breakoutand-playing-a-mute-gay-man-in-geethu-mohandas-film-7700591.html.

Praveen, S.R. “'Moothon' Review: a Brave Statement from Geetu Mohandas.” The Hindu, The Hindu, 9 Nov. 2019, www.thehindu.com/entertainment/movies/moothon-reviewa-brave-statement-from-geetu-mohandas/article29924825.ece.

Stanford University Press. "Amorous Acts: Lacanian Ethics in Modernism, Film, and Queer Theory: Frances L. Restuccia.” Stanford University Press Home Page, www.sup.org/books/title/?id=5333.

Sudhish, Navamy. “'Moothon': Finally, a Malayalam Film That Depicts Queer Love Sensitively and without Stereotypes." The Hindu, The Hindu, 29 Nov. 2019, www.thehindu.com/entertainment/movies/moothon-finally-a-malayalam-film-thatdepicts-queer-love-sensitively-and-without-stereotypes/article30115255.ece.

Moothon. Dir. Geethu Mohandas. Perf. Nivin Pauly, Roshan Mathew, Sanjana Dipu. Mini Studio;JAR Pictures, 2019. 
Deshadanakkili Karayarilla. Dir. Padmarajan. Perf. Karthika, Shari, Mohanlal. Burton Movies, 1986.

Chanthupottu. Dir. Lal Jose. Perf. Dileep, Gopika. Lal, 2005. 